\title{
Nytt multisenterprosjekt om villet egenskade blant barn og unge i Europa
}

Ved M ette Y stgaard

\begin{abstract}
Villet egenskade som ikke fører til døden, ser ut til å være et utbredt problem blant unge i hele E uropa (Schmidthe et al. 1996). D ette bekymrer. D et gjenspeiler smertefulle unge liv, avmakt og psykiske problemer ( $G$ røholt 2000), og dessuten en betydelig økt risiko for at mange unge senere vil ta sitt eget liv ( $\mathrm{H}$ awton et al. 1993).
\end{abstract}

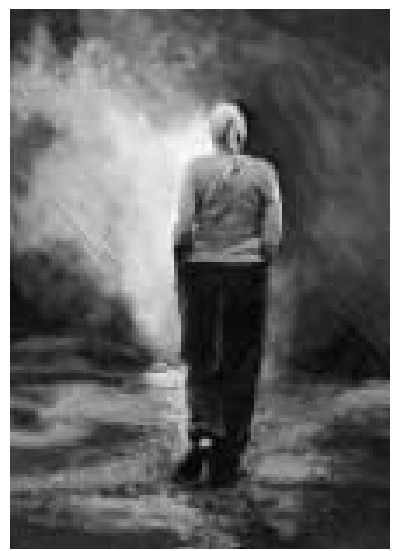

Ikke desto mindre er empiriske data om selvmordsforsøk og villet egenskade blant barn og unge begrenset. Den beste informasjonen om omfanget og utvikling over tid har vi fra England ( $\mathrm{H}$ awton et al. 2000). Det ble påvist en økning på 28,1 \% blant alle unge under 20 år som fikk behandling ved 0 xford sykehus i perioden 1985 til 1995. I dette materialet, som i andre undersøkelser, er det flest jenter som gjør selvmordsforsøk, men problemet øker like mye for både gutter og jenter.

R egistreringer på sykehus gir imidlertid på ingen måte et fullstendig bilde av omfanget. Surveyundersøkelser, oftest gjennomført i skolen, antyder opptil 100 ganger så høye tall. I en landsrepresentativ norsk skoleundersøkel se rapporterer 8,3\% av elevene at de har prøvd å ta livet av seg en eller flere ganger i løpet av oppveksten (Rossow \& W ichstrøm 1994). De fleste hadde ikke fått medisinsk hjelp. $M$ ange var heller ikke fanget opp av familie, Iærere eller andre nære voksne. Så mange som $60 \%$ av guttene og $45 \%$ av jentene hadde ikke fortalt noen om hendelsen. Vi vet lite om hva som skjuler seg bak disse tallene. H va slags og hvor alvorlige skader er det snakk om? H va var hensikten med skaden? O g hvor stort er det faktiske omfanget sammenlignet med dem som blir registrert ved sykehus-ene? H vor søker ungdom hjelp, og hva kjennetegner dem som ikke făr hjelp? En forebyggende of-fensiv med ønske om å gripe inn så tidlig som mulig, forut-setter bedre kunnskap og forståelse av disse problemene.

\section{CASE-studien}

For å få mer og grundigere kunnskap om dette problemfeltet har 10 sentre i Europa startet et felles forskningsprosjekt "C hild and A dolescence Self-H arm in Euroupe" (CA SE). G jennom å anvende lik metode og gjennomføre undersøkelsen i samme tidsperiode i mange europeiske land, kan en studere likhetstrekk og forskjeller mellom landene når det gjelder omfang, risikofaktorer, hjel petilbud og hjelpsøkingsatferd.
En vesentlig side ved undersøkelsen er at hvert land gjennomfører både en sykehusundersøkel se og en skoleundersøkelse. I sykehusundersøkelsen registrerer og kartlegger en alle barn og unge under 20 år som blir medisinsk behandlet på sykehus på grunn av villet egenskade, i første omgang $\mathrm{i}$ tre år. A lle deltakerlandene samler inn kjernedata om kjønn, alder, metode for egenskade og gjentatte egenskader i et nærmere definert sykehusområde.

Skoleundersøkelsen blir gjennomført som en anonym spørreskjemaundersøkelse blant et representativt utval g på 5000 15- og 16-åringer i hvert av deltakerlandene.

I løpet av en skoletime besvarer elevene spørsmål om livspåkjenninger, rus, villet egenskade, metode, intensjon og gjentakelse, selvmordstanker, holdninger til selvmordsatferd, selvfølelse, psykisk helse, mestring og hvor de søker hjelp dersom livet kjennes umulig. I det norske skjemaet har vi lagt til spørsmål om opplevelse av tilhørighet, trivsel og sosial støtte fra familie, venner og lærere og holdninger til avvikende seksuell identitet.

\section{Oppland og Hedmark som prosjektfylker}

$\mathrm{N}$ ational Child Bureau i London har ansvar for å koordinere det internasjonale arbeidet som er finansiert av European Commission Daphne Initiative og Economic and Social Science Research Council. Seksjon for selvmordsforskning og -forebygging er ansvarlig for den norske undersøkelsen som blir gjennomført i H edmark og 0 ppland. Vi er nå halvveis i en spennende og intensiv datainnsamling. Sykehusundersøkel sen startet ved sentral sykehusene i H edmark og 0 ppland $\mathrm{i}$ januar 2000. I fjor høst ble skoleundersøkelsen gjennomført blant elever på grunnkurs ved samtlige videregående skoler i 0 ppland. PP-tjenesten ved skolene var ansvarlig for gjennomføringen. I sine skriftlige tilbakemel dinger etter undersøkelsen rapporterte PP-rådgiverne om konsentrerte, positive og interesserte elever som syntes det var meningsfullt å svare på spørsmål som angikk alvoret i livene deres. For egen del så rådgiverne undersøkel sen som en god mulighet til å komme i kontakt med hele ungdomsgruppen. På slutten av timen fikk hver elev en brosjyre med informasjon om hvor i fylket de kan søke hjelp. Slik har prosjektet allerede hatt lokale ringvirkninger. En tilsvarende innsamling vil bli gjort i H edmark i september 2001. 0 gså i H edmark har samtlige skoleledere stilt seg positive til at deres skole skal delta. A It ligger derfor til rette for å få et godt, representativt materiale.

Det internasjonale analysearbei det er i startfasen. Det arbeides nå med å kategorisere elevenes svar om villet egen skade. A lle som har svart ja på spørsmålet "H ar du noen gang med vilje tatt en overdose eller på annen måte forsøkt å skade deg selv?" er bedt om å beskrive hva de gjorde den gangen. $\AA$ få et mer nyansert bilde av omfang, skademetode og intensjon regner en med vil gi viktig ny kunnskap.

Det blir satt strek for datainnsamlingen våren 2002. Etter den foreløpige planen vil det foreligge en felles monografi med hovedresultater fra alle deltakerlandene sommeren 2002, etterful gt av mer avgrensede vitenskapelige artikler. M en undersøkelsen har også et mer direkte forebyggende siktemål. Så snart vi har bearbeidet de norske dataene, vil vi gi tilbakemeldinger til skole- og helsemyndigheter om resultater som kan være av særlig interesse for å planlegge forebyggende tiltak i skole og nærmiljø.

(Referanser, se s. 13)

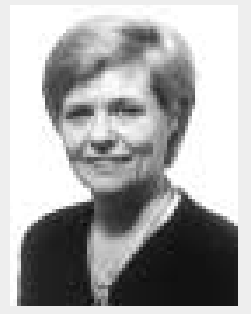

M ette $Y$ stgaard er cand.paed. og forsker ved SSFF. H un har mangeårig erfaring fra pptjenesten. H ennes forskning er særlig konsentrert om selvmordsatferd $i$ et stress mestringsperspektiv.

$\mathrm{H}$ un er nasjonal prosjektleder for $\mathrm{C}$ hild and A dolescence Self-H arm in Europe (CA SE). 